\title{
Value Creation of Strategic Investors under Convertible Bond Investment-A Case Study of Wharf (Holdings) Limited
}

\author{
Wei Huang \\ School of Business Administration, South China University of Technology, Guangzhou, China \\ Email: vera527@foxmail.com
}

How to cite this paper: Huang, W. (2019) Value Creation of Strategic Investors under Convertible Bond Investment-A Case Study of Wharf (Holdings) Limited. Open Journal of Business and Management, 7 , 275-291.

https://doi.org/10.4236/ojbm.2019.71019

Received: December 22, 2018

Accepted: January 18, 2019

Published: January 21, 2019

Copyright () 2019 by author(s) and Scientific Research Publishing Inc. This work is licensed under the Creative Commons Attribution International License (CC BY 4.0).

http://creativecommons.org/licenses/by/4.0/

\begin{abstract}
This paper analyzes the case of Wharf's participation in Greentown China's corporate governance under the investment of convertible bonds, and brings the case of market value growth. It reveals that the strategic investors have passed the three stages of "value support-value driven-value realization". The bond issuer realizes value creation and achieves a win-win situation for both parties. The study found that strategic investors and bond-issuing companies have complementary resources and positioning strategies to provide strong value support for cooperation between the two parties. The key processes driven by value include the investment phase and the corporate governance phase. In the investment phase, choosing the right financing method and designing the refined terms provide the basis for strategic investors to participate in corporate governance. In the corporate governance stage, strategic investors can restrain overinvestment by issuing sound financial policies bonds, and participate in the investment decision-making of bond-issuing enterprises to create business synergies. The realization of value is reflected in the two aspects of market value improvement and business improvement.
\end{abstract}

\section{Keywords}

Strategic Investors, Convertible Bonds, Corporate Governance, Market Value Management

\section{Introduction}

The introduction of strategic investors has been adopted by many commercial banks and state-owned enterprises in China during the transition period. In recent years, many well-known companies have introduced strategic investors, Alibaba strategically invested in Sina Weibo to deploy social e-commerce, push- 
ing up Sina's stock price; Keda Xunfei introduced China Mobile as a strategic investor and the market value increased sharply in the short term. In 2012, Wharf, in the role of strategic investor, invested in convertible bonds in Greentown China, which was in the midst of a financial crisis, to "turn the crisis into safety" in terms of finance and operations. In the first half of the year, Greentown China's dynamic P/E ratio rose from 2.8 to 8.4 , the market value had increased by 3 times. In the current research, some scholars believe that listed companies' convertible bond financing is a typical "backdoor equity" financing (Wang Dongnian et al., 2009) [1], and some scholars believe that the company issues convertible bond for continuous financing (Korkeamaki and Moore, 2004) [2]. Some scholars also believe that investors can realize corporate governance functions for bond issuers through convertible bond investments (Zhang Gaoqing et al., 2009) [3]. However, there are few studies on strategic investors and convertible bond financing, as well as how strategic investors can play a synergistic role and participate in corporate governance to influence the value of bond issuers. Then, can strategic investors be able to achieve corporate governance for bond issuers through convertible bond investment and create value for bond issuers? What is the mechanism of this value creation? Compared with investment methods such as additional issuance and share allotment, what is the uniqueness of debt investment in influencing the value of bond issuers?

This paper adopts the case study method, taking the example of Wharf's Investment Greentown China as an example to explore the complex process of strategic investors' convertible bond investment, and construct the process mechanism of strategic investors to create value for bond issuers through convertible bond investment, construct a corresponding value creation model. On the basis of answering the above three questions, enrich the theory of strategic investors and corporate investment, and create value for strategic investors for bond issuers, provide beneficial theory and practical experience in strategic synergy, business integration and participation in corporate governance.

\section{Literature Review and Research Framework}

\subsection{Related Research on the Cause of Convertible Debt}

Convertible bond is a bond that the bondholder can convert the bond into the common stock of the company according to the agreed price at the time of issuance. There are three more representative hypotheses about the aspects of the convertible debt issue: the backdoor equity hypothesis, the continuous financing hypothesis, and the risk transfer hypothesis. Stein (1992) [4] proposed the backdoor equity hypothesis. He believes that in the case of information asymmetry that makes traditional stocks unattractive, companies can use convertible bonds to obtain financing opportunities; convertible bonds play an important role in relieving information asymmetry; high-risk companies are more likely to use convertible bonds. Chinese scholars have shown that the convertible bond financing of listed companies in China is a typical "backdoor equity" financing 
(Wang Dongnian et al., 2009) [1], and found that the wealth effect of the issuance of convertible bonds and the growth opportunities and the financial distress risk level of the issuing companies are positive related (Qu Wenzhou et al., 2009) [5]. Mayers (1998) [6] proposed the continuous financing hypothesis, which is in line with the idea of the backdoor equity hypothesis. The Mayers model regards convertible bonds as an effective way for companies with good prospects to finance future potential investment opportunities. He believes that the company's use of recallable convertible bonds can not only meet the funding needs of the company stage, but also reduce the issuance costs of subsequent financing. He also pointed out that convertible bonds are more valuable to companies with outstanding careers. Korkeamaki and Moore (2004) [2] pointed out that if a company issues convertible bonds for continuous financing, the convertible bonds should have sufficient flexibility to coordinate the company's subsequent investment time. The basic idea of the risk transfer hypothesis is that there is a conflict of interest between shareholders and creditors, and convertible bonds can mitigate the conflict of interest between shareholders and creditors (Green, 1984) [7].

\subsection{Research on the Governance Function of Convertible Bond Companies}

In addition to convertible bond issuance motivation, there are also scholars to explore the corporate governance function of convertible bonds. Zhang Gaoqing and Lian Peng (2009) [3] examined the arbitrage encroachment of institutional investors based on stock price manipulation in the convertible bond financing of Hunan Hualing Pipeline Co., Ltd. and their collusion with major shareholders in the voting process of stock split reform, revealing that the arbitrage encroachment of institutional investors is the main reason for the sharp drop in stock prices after the issuance of convertible bonds. Zhu Jigao (2012) [8] took Bain Capital's investment in Gome Convertible Bonds as a case background, and concluded that convertible bonds are not only a financing tool, but also have corporate governance functions, enabling institutional investors to participate in the corporate governance practice of bond issuing companies.

\subsection{Research on the Relationship between Strategic Investors and Issuers}

Strategic investors are legal persons introduced by enterprises according to their own purposes, who have competitive business in the same industry and are located in the upstream and downstream of the same industry and in other industries (Sheng Yuhua et al., 2014) [9]. The existing literature focuses on the impact of strategic investors on firm performance and which strategic investors have a more significant impact on firm performance.

There are differences in the results of empirical research on the impact of strategic investors' participation in corporate governance on performance. Relevant research with a positive view: Megginson and Netter (2001) [10] found that 
after the introduction of overseas strategic investors, the company's profitability and operational efficiency have improved significantly. The analysis results of Hasan and Xie (2012) [11] show that the active participation of foreign strategic investors in bank management improves the corporate governance model of Chinese banks. The research by Zhang Zongyi et al. (2010) [12] shows that strategic investors improve long-term performance of an enterprise by participating in corporate governance and influencing financial strategy choices. However, many scholars have put forward the opposite views: Yin Xiaobing et al. (2009) [13] found that the company's operating performance, management level, financial status and overall performance were not improved after the introduction of strategic investors.

Regarding the research on which strategic investors have more significant impact on corporate performance, in theoretical research, Zhang Shaohua et al. (2012) [14] mentioned that the strategic investors introduced by enterprises are related to corporate business. It is an ideal strategic investor to complement resources, technology and management. Li Jian, Jin Zhanming (2007) [15] believes that the success of strategic alliances depends mainly on the matching of alliance partners, and the factors affecting the matching of alliance partners are the consistency of strategic objectives, the matching of resources, the similarity of markets, the differences of culture, etc. Sheng Yuhua et al. (2014) [9] found through empirical research that the shareholding ratio of competitive and irrelevant strategic investors is inversely $\mathrm{u}$-shaped related to the performance of listed companies, the shareholding ratio of complementary strategic investors is significantly positively correlated with the performance of listed companies and the proportion of strategic investors entering the board of directors is positively related to the performance of listed companies.

The existing researches provide a reference for this article, but do not give a complete explanation of how the strategic investor convertible bond investment can create value for the issuing company. On the basis of the fusion of previous research, this paper focuses on the following three aspects, in order to explore the systematic theoretical model of the value creation of strategic investors under the investment of convertible bonds: first, convertible bond investment's difference from rights offering and additional issuance in terms of value creation; the second is to explore the specific ways and achievements of strategic investors to participate in the corporate governance of issuing companies; the third is to analyze the theory of convertible bonds of strategic investors combined with the theory of market value management.

\subsection{Preliminary Theoretical Model}

Considering the continuous financing hypothesis of convertible bonds and the research results of strategic investors, combined with Lu Zhenghua et al. (2014) [16] based on the value-driven market value management framework, the preliminary model of the value creation mechanism of strategic investors' convertible 
bonds is preliminarily sketched after the logical derivation. In the model, it mainly includes three stages: "value support-value drive-value realization". The theory of continuous financing of convertible bond issuance is a strong support for value creation by strategic investors and debt bond-issuing enterprises. The design of convertible bond clauses in the investment stage and participating in the post-investment management stage of bond-issuing companies' corporate governance are the key steps in value-driven. The realization of creation can be examined from financial performance and total market capitalization (Figure 1).

\section{Case Selection and Introduction}

\subsection{Case Selection}

This paper uses the exploratory case study method and select the single case of the Wharf (Holdings) Limited (Hong Kong Stock Exchange stock code: 0004; be abbreviated as Wharf) investment in Greentown China (Holdings) Limited (Hong Kong Stock Exchange stock code: 3900; be abbreviated as Greentown China) convertible bonds. The reason for choosing this case are: first, Greentown China faced a huge debt crisis before investing in Wharf. After the Wharf entered as a strategic investor, it experienced major business and financial adjustments. The dynamic P/E ratio rose from 2.8 to 8.4, and the market value increased by 3 times. The market value management model of this case is obvious and analyzable. Second, Strategic investor Wharf experienced the whole process of entering Greentown China as a strategic investor to exiting from 2012 to 2016. The case process is complete, which is beneficial to examine the market value management results and mechanism.

\subsection{Case Introduction}

Wharf, founded in 1886, is one of the largest real estate investment companies in Hong Kong with a strategic focus on the development of real estate and infrastructure businesses and core competitiveness in land acquisition, financing, project development, design, construction and marketing. The most famous investment properties of Wharf are Harbour City and Times Square, which provide the Group with robust recurring benefits and value-added opportunities.

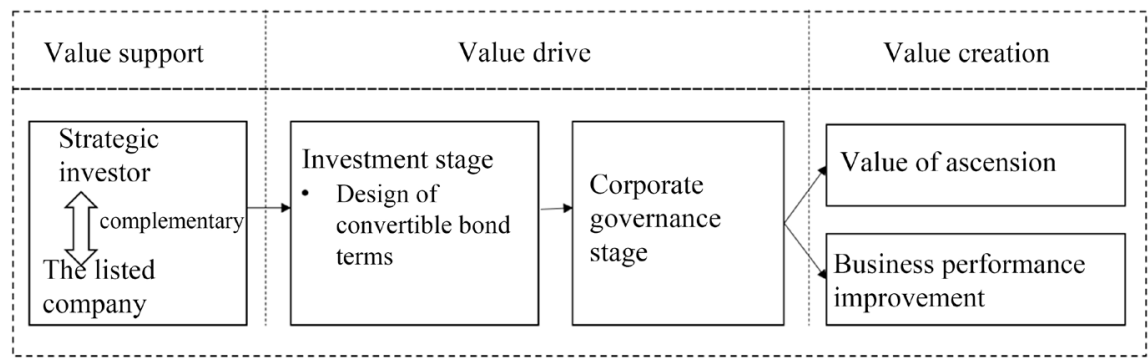

Figure 1. The preliminary model of value creation mechanism of strategic investors convertible bonds. 
Wharf announced in 2007 that it would overweight the mainland market and announced that future mainland assets will reach $50 \%$ of the Group's total assets. As of the end of 2011, Wharf's business assets in China accounted for $40 \%$ of the Group's total assets, and its business contribution had reached $21 \%$ of the Group's core earnings. The real estate development model in the Mainland is similar to the Hong Kong model, which is a vertical operation chain centered on real estate development enterprises, including investment in land acquisition, development and construction, marketing and sales, and property management. It is usually completed by a single company and can be called "The all-rounder developer. The key success factors for real estate companies in the Mainland are: having good social relationships to acquire rich land, good financing capabilities and excellent operational capabilities. Wharf has sufficient self-owned funds and good operational capabilities. However, in order to expand its good information and relationship network in the Mainland and quickly respond to market changes, it is actively seeking partners for development in the Mainland.

In 2012, under the influence of severe macroeconomic regulation and control, Greentown China, which had a large capital gap and needed financing, became the target of Wharf s intention cooperation. Greentown China is one of the most successful real estate developers in China. Its headquarters is located in Hangzhou, Zhejiang Province. It was established in 1995 and listed in Hong Kong in 2006. In the real estate industry, Green City China has been known for its high quality and high debt, and it maintained a high growth rate. And reasons for the cooperation of Wharf and Greentown China are as following: First, by the end of 2011, according to the annual report, Greentown China had rich land reserves in the mainland covering more than 41 million square meters of gross floor area, more than three times that of Wharf. Second, Greentown China is deeply rooted in the mainland market and has a good social network that complements Wharf. Third, due to the high asset-liability ratio and debt crisis, the Greentown China market valuation in the first half of 2012 was much lower than that of the same industry, with investment space.

\section{Case Analysis}

\subsection{Value Support: Strategic Investors and Bond-Issuing Enterprises Have Complementary Resources and Positioning Strategies}

The complementary resources and positioning of strategic investors and bond-issuing enterprises are strong support in the process of strategic investors' investment. The matching of Wharf and Greentown China resources stems from the following points:

\subsubsection{Financial Resources and Business Resources Complement Each Other to Facilitate Cooperation between the Two Parties}

1) Wharf has sufficient cash to solve the "immediate need" of Greentown China's high asset-liability ratio. Wharf has adopted a relatively conservative 
financial strategy for a long time, at the end of 2011, cash and cash equivalents amounted to 25.46 billion yuan, the asset-liability ratio was only $33.68 \%$, and the ratio of monetary funds to current liabilities reached $102 \%$, indicating that the Wharf Group has sufficient self-owned capital for external investment. Greentown China has faced high asset-liability ratio problems at the end of 2011, with an asset-liability ratio of $86.21 \%$, cash and cash equivalents of only 3.615 billion yuan, and monetary funds/current liabilities of only $4 \%$. Greentown China was faced with a relatively serious problem of paying current liabilities, and it was in urgent need of external financing. In addition, Wharf can assist Greentown China in building a valuable brand in the international financial market (Table 1).

2) Greentown China's rich domestic land reserves lay the foundation for long-term cooperation between the two parties. Greentown China is deeply rooted in the domestic market and has abundant land reserves, which coincides with the strategy of Whalf to "actively expand its domestic assets". Greentown China pursued scale expansion with high debt ratio before 2011, it had 105 projects under construction or to be developed, and had land reserves of more than 41 million square meters of total construction area nationwide, which can ensure the sustainable and stable development of the group in the next five to seven years. At the end of 2011, Wharf's land reserves in the mainland was only about 12 million square meters, accounting for less than one-third of Greentown China's land reserves; its mainland assets accounted for only $40 \%$ of the group's total assets. Greentown China has accumulated rich development capabilities in different places in the country for many years, including the ability to communicate and negotiate with the government and the ability to replicate and expand in the cities of the interior. For real estate developers, land acquisition is one of the core competitiveness and a key success factor for Wharf's urban development in the mainland. Greentown China and Wharf complement each other in terms of land reserves and land acquisition capacity, Greentown China can help Wharf conduct domestic market expansion.

\subsubsection{Product Market Positioning Is Similar, Strategic Convergence Reduces Cooperation Barriers}

1) The similarity of the market and product positioning between the two parties helps to develop their expertise in property development and management. Both Greentown and Wharf are positioned to develop high-end properties in terms of products. Over the years, Greentown has formed a series of high-quality

Table 1. Comparison of financial status between Wharf group and Greentown China.

\begin{tabular}{ccc}
\hline Company short name & Greentown China & Wharf Group \\
\hline Asset-liability ratio & $86.21 \%$ & $33.68 \%$ \\
Monetary funds/current liabilities & $4 \%$ & $102 \%$ \\
Cash and cash equivalents & 3.615 billion RMB & 25.460 billion RMB \\
\hline
\end{tabular}

Data source: According to Wharf, Greentown China 2011 Annual Report. 
products that are widely accepted by the market, such as villas, flat-level bureaucrats, multi-storey apartments, urban complexes, large-scale communities and commercial properties. The property and residence of the Wharf are both high-end luxury positioning, and the development and management of high-end shopping malls are particularly outstanding. In terms of the market, Greentown is located in the Yangtze river delta and other important cities (such as Nanjing, Suzhou, etc.), important cities in the Bohai rim economic circle and some provincial capitals in the mainland, while Wharf is mainly located in the East China region (such as Suzhou and Wuxi, Changzhou, etc.), West China region (Chongqing, Chengdu), the two in the market layout overlaped, but also promoted the cooperation between the two sides of regional expansion.

2) The convergence of financial strategies between the two parties can accelerate the strategic transformation of Greentown China. After years of rapid expansion, Greentown China left behind the "sequel" of high asset-liability ratio. In 2012, its strategic goal was that Greentown would no longer pursue scale expansion through high debt ratio, but focus on relying on brand and management output to achieve stable development under the premise of ensuring high quality, and reduce debt ratio to a reasonable level as soon as possible, which is a process of transition from radical to steady. The main strategic goal of Wharf in 2012 was to "actively expand assets in mainland", which was a process from more conservative to positive expansion. The difference in financial strategy between the two parties had been reduced, which was beneficial to Wharf assists Greentown to formulate and implement the steady financial policy and the management measure.

\subsection{Value-Driven: Investment Stage Financing, Convertible Bond Design and Corporate Governance Are Value-Driven Fundamental Factors}

\subsubsection{Investment Stage: Design of Financing Methods and Convertible Bonds}

1) Convertible Bonds Take into Account both Capital Demand and Stable Management Control

From June to August 2012, Wharf purchased Greentown shares three times, with a subscription price of $\mathrm{HK} \$ 5.2$ per share. Wharf's $24.6 \%$ stake makes it the second largest shareholder of Greentown. At that time, Greentown China still had a capital requirement of 2.55 billion Hong Kong dollars. It faced the situation of continuing financing to Wharf. The specific financing method can be selected to simulate Table 2 .

By comparison, it can be seen that if Greentown China directly issues corporate bonds, it will face higher annual interest rate problems and further push up the asset-liability ratio of Greentown, which will not benefit the long-term situation of alleviating high debt ratio and tight capital. If Greentown China continues to issue shares to Wharf in accordance with HK\$5.2/share, Wharf will hold approximately $47 \%$ of the shares in Greentown China, which will significantly 
Table 2. Greentown China's financing needs and different financing methods.

\begin{tabular}{|c|c|c|c|}
\hline Financing & The Convertible Bond & Corporate Bonds & Allotment of Shares \\
\hline Fund demand & $\begin{array}{l}2.55 \text { billion Hong Kong } \\
\text { dollars }\end{array}$ & $\begin{array}{c}2.55 \text { billion Hong Kong } \\
\text { dollars }\end{array}$ & $\begin{array}{l}2.55 \text { billion Hong Kong } \\
\text { dollars }\end{array}$ \\
\hline Wharf Equity & $\begin{array}{l}24.6 \% \text { (After the } \\
\text { conversion } 35.13 \% \text { ) }\end{array}$ & $24.6 \%$ & About $47 \%$ \\
\hline Annual Interest Rate & $9 \%$ & $12.5 \%^{1}$ & 0 \\
\hline
\end{tabular}

Data source: According to announcement of the Wharf Company and author's estimation.

dilute the shareholding ratio of the management, which is not conducive to the stability of control.

The reason for the selection of convertible bonds for this capital increase is mainly due to the following aspects: first, the management share of the management will not be diluted for the time being, and the control of Greentown China will be stabilized. Second, the earnings per share will not be diluted, it will help Greentown China's earnings per share to maintain steady growth, which is conducive to market value growth. Third, for Greentown management, it faces the pressure to redeem convertible bonds within a certain period of time, which is conducive to stimulating its business decision-making and helps to curb excessive investment. Fourth, for strategic investors, the cost of convertible bond investment is locked in, even if Greentown China's performance and market value performance are not as expected, Wharf can still lock interest income from convertible bonds.

2) Design of Convertible Bond Clause: Strong Constraint on Cooperation between the Two Parties

The design of the convertible bond clause in the investment phase is one of the most important factors for the cooperation between the two parties. The convertible bond clause provides a contractual constraint for the Wharf subsequent participation in Greentown China corporate governance. The following table summarizes the terms of the convertible bond agreement (Table 3 ).

First, design a full conversion period to coordinate the company's subsequent investment. This clause stipulates that the convertible bonds can be converted at any time after the expiration of the three-year period from the date of issue. However, if one of the following circumstances occurs, the convertible bonds can be converted: First, if an offer is made to greentown shareholders for all shares in circulation in greentown China, the convertible bond may be converted at any time upon or after the formal offer is made in accordance with applicable rules or regulations. Second, the event of default occurs and persists, and the convertible bond can be converted. The clause also stipulates the issuer's redemption clause: after the issue date, the issuer may redeem all or part of the convertible bonds at any time, together with all outstanding interest and accrued interest on the original redemption date, the redemption price shall be calculated as a percentage of the amount specified below. These two terms stipulated a ${ }^{1}$ Refer to Greentown China's average cost of capital. 
Table 3. Summary of the terms of the Greentown China Convertible Bond Agreement.

\begin{tabular}{|c|c|}
\hline Issuer & Greentown China \\
\hline Investor & Wharf \\
\hline $\begin{array}{l}\text { Convertible bond } \\
\text { principal }\end{array}$ & HK $\$ 2.5$ billion \\
\hline Issue price & $100 \%$ of the convertible debt principal amount \\
\hline Expiry date & No expiration date \\
\hline Interest & $\begin{array}{l}\text { In the five years prior to the issuance, the annual interest rate of the notes is } \\
9 \% \text {; the fifth to tenth years are } 9 \%+2 \% \text {; the tenth year is } 9 \%+2 \%+\text { the } \\
\text { Treasury bond rate. Interest is paid on the first anniversary after the date of } \\
\text { issue and is paid semi-annually. }\end{array}$ \\
\hline & $\begin{array}{l}\text { Change at any time after the expiration of the } 3 \text {-year period from the date of } \\
\text { issue. However, 1) if an offer is made to greentown shareholders for all shares }\end{array}$ \\
\hline $\begin{array}{l}\text { Conversion } \\
\text { period }\end{array}$ & $\begin{array}{l}\text { in circulation in greentown China, the convertible bond may be converted at } \\
\text { any time upon or after the formal offer is made in accordance with applicable } \\
\text { rules or regulations; or 2) The event of default occurs and persists, and the } \\
\text { convertible bond can be converted. }\end{array}$ \\
\hline $\begin{array}{l}\text { Conversion } \\
\text { price }\end{array}$ & Greentown China shares per share of 7.40 Hong Kong dollars. \\
\hline $\begin{array}{c}\text { Issuer } \\
\text { redemption }\end{array}$ & $\begin{array}{l}\text { After the issue date, the issuer may redeem all or part of the convertible bonds } \\
\text { at any time, together with all outstanding interest and accrued interest on the } \\
\text { date of the original redemption, the redemption price is as follows: } 1 \text { ) within } \\
\text { the first anniversary (excluding the day, the same below), at the principal } \\
\text { amount of } 103.5 \% \text {; ) at the second anniversary, at the principal amount of } \\
107.0 \% \text {; } 3 \text { ) within the third anniversary, at the principal amount of } 110.5 \% ; 4 \text { ) } \\
\text { within the fourth year, at the principal amount } 114.0 \% ; 5 \text { ) After the fourth } \\
\text { anniversary date, } 117.5 \% \text { of the principal amount. }\end{array}$ \\
\hline
\end{tabular}

Source: Organized according to the announcement of the Wharf Company.

three-year conversion period and also gave Greentown China the right to redeem convertible bonds at any time. For Greentown China, there was relatively ample time for capital operation and company operation, and within three years, it obtained relative liquidity for redemption of convertible bonds, avoiding losing control due to dilution of management's equity.

Second, strategic investors get board seats to participate in corporate governance in the future. After the completion of the transaction, Wharf won the Greentown China's two-member board seat; and formed an investment committee to provide guidance to the company on investment matters. There were three members, and there was a seat in Wharf. In addition, this clause also stipulates that when the debt ratio of the company is $100 \%$ or above and the member companies of greentown China group purchase land or invest in any property development project without the written consent of the majority of the members of the investment committee, the event of default will occur and the convertible bonds can be converted. The establishment of the Investment Committee and the dispatch of representatives to the Greentown China Board of Directors had allowed Wharf to participate in Greentown Corporate Governance with contractual constraints, enabling Wharf to export its sound financial policies and operational decisions. 
Third, a stable management team laid the foundation for the future development of Greentown China. The Convertible Bond Agreement stipulated: First, Song Weiping, Chairman of the Board of Directors of Greentown China, Executive Vice President and Chief Executive Officer Shou Bainian promised to continue working in Greentown within five years; Second, Mr. Song, Mr. Shou or Mr. Luo Yuming (The executive directors of Greentown China) need to control a total of $30 \%$ or more of the voting rights of Greentown China, otherwise the two-year non-disposal commitment will be invalid. This is actually a binding agreement to prevent high-level, control changes from causing fluctuations in Greentown operations. For strategic investors Wharf, it is the basis for close cooperation between the two parties.

\subsubsection{Corporate Governance Stage: Strategic Investors Play Corporate Governance Functions for Value Enhancement}

After the convertible bond investment, strategic investors' post-investment management of the issuing company is an important focus of value enhancement. The most important thing is to exert the function of corporate governance through the constraints of the convertible debt clause.

1) Steady Financial Policy Output Suppresses Excessive Investment

In order to protect the interests of strategic investor Wharf, the convertible bond agreement stipulated that strategic investors should obtain board seats and set up investment committees to provide guidance to the company on investment matters. In addition, the two parties had added special terms to the convertible bond agreement: First, Greentown China promises that there will be no changes, events, circumstances or other individual or overall business, operation, financial status, assets or assets of the Greentown China Group, which resulted in a net reduction in the consolidated net asset value of greentown China group by more than $30 \%$ of the consolidated net asset value shown in the audited financial statements of greentown China group for the year ended December 31, 2011; Second when the company's debt ratio is $100 \%$ or more and the members of the Greentown China Group acquire land or investment and any property development projects without the written consent of the majority of the members of the investment committee, the convertible bonds can converted, not subject to a 3-year conversion period. From the above two clauses, it can be seen that wharf plays a role in greentown China investment committee through the provisions of the convertible bond agreement, and implements the sound financial policy and corporate governance measures in greentown China's business, which is complementary to the previous financial policy of greentown China.

In addition, according to the continuous financing theory, the convertible bond holder does not execute the conversion option but accepts the redemption of the bond, which is beneficial to control the over-investment problem. In addition, under the special terms of convertible bonds, the financial policies and business philosophy of convertible bond investors can be further implemented to the issuing company, which has a more direct impact on controlling excessive 
investment behavior.

2) Participate in Company Investment Decision-making and Create Business Synergy

Wharf will cooperate with greentown not only in strategic investment, but also in future business cooperation.

In addition, Wharf also obtained voting rights for foreign investment through a seat of the Investment Committee. According to WIND, from 2012 to 2015, the land area of the cooperation between the two parties was 250,000 square meters, the planned construction area was 592,200 square meters, and the total land price reached 6.729 billion yuan. The land acquisition between the two parties is mainly for residential land in Hangzhou, Dalian and Shanghai. These places are the places where Greentown China is deeply cultivated. The proportion of the interests of both parties is the same, except that the land parcel in Dalian is the Wharf equity ratio of $60 \%$, Greentown China is $40 \%$. Together with Greentown China, it develops the Greentown Wharf-Qiantang Mingyue and Greentown.Jiangjiang No.1 in Hangzhou, which are commercial and residential properties with a land area of 61,300 square meters and a planned construction area of 154,900 square meters. The total land price reached 4.834 billion yuan. The close cooperation between the two parties in acquiring land and developing property fully reflects their business cooperation. Greentown China provided Wharf with opportunities for development in the mainland market and assisted in establishing its brand in the mainland market. Wharf was also able to provide Greentown China with excellent means of property development and operation for reference, so that both sides could give full play to their advantages to achieve a win-win situation.

\subsection{Value Realization: Realizing Market Value Improvement and Business Improvement}

\subsubsection{Capital Side: Realizing Market Value Increase}

The investment of strategic investment will be repaired by the bond issuers in terms of asset-liability ratio; reduce the financing cost of bond-issuing enterprises and reduce financial risks; release future growth signals, boost the market valuation of bond-issuing enterprises, ease the financial crisis of bond-issuing enterprises, and realize financing sustainable development.

1) The Balance Sheet Has Been Effectively Repaired

In 2012, after Wharf strategically invested in Greentown China, examining the Greentown's financial indicators in terms of capital structure and solvency, it shows that its asset-liability ratio is maintained within the range of $73 \%-77 \%$; The proportion of liabilities decreased year by year, from $91.7 \%$ in 2012 to $67.39 \%$ in 2016; The ratio of monetary funds to current liabilities also increased year by year, from $0.04 \%$ in 2012 to $0.26 \%$ in 2016 . At the end of 2012 , Greentown China's net gearing ratio fell to $49 \%$, and the asset-liability ratio fell from $86.2 \%$ (2011) to $76.8 \%$ at the end of 2016. This showed that Greentown China's financial situation was getting healthier and more stable, which proved that 
Greentown China had slowed the pace of over-expansion of investment (Figure 2).

By comparing the valuation of a number of real estate companies with the net debt ratio, it can be found that the capital market tends to give a large discount to enterprises with high debt ratios. At present, companies with a net debt ratio higher than $80 \%$ are far less than $80 \%$ of companies with PE. Therefore, the repair of the asset-liability ratio has a strong positive impact on the market value of Greentown China.

\section{2) Reduce Financing Costs and Reduce Financial Risks}

From the perspective of capital cost, Greentown obtained funds at a nominal cost of $12.5 \%$ per year in the case of a higher asset-liability ratio in 2012, while the Wharf capital cost ratio was $6 \%$. The two parties agreed to pay an annual interest rate of $9 \%$ for the five years prior to the issuance of convertible bonds. For Greentown China, the overall financing cost was reduced and the risk of short-term debt service was reduced.

\section{3) Release Future Growth Signals to Boost Market Valuation}

Strategic investors, through convertible bond investment, release signals to the market for future profit growth of bond issuers, which can increase investors' information on bond issuers, affect investors' valuation of the company and investment decisions, and influence stock price and market value of debt companies. It can be seen from this case that after the Wharf invested in Greentown, the market value of Greentown China had risen against the trend and was relatively stable for a period of time. It can be seen that the investment of Wharf had not only improved the Greentown China's financial situation from the perspective of the company, but also signaled the steady development of Greentown China from the external market (Figure 3).

\subsubsection{Industry Side: To Achieve Operational Improvement}

\section{1) Realizing Strategic Transformation}

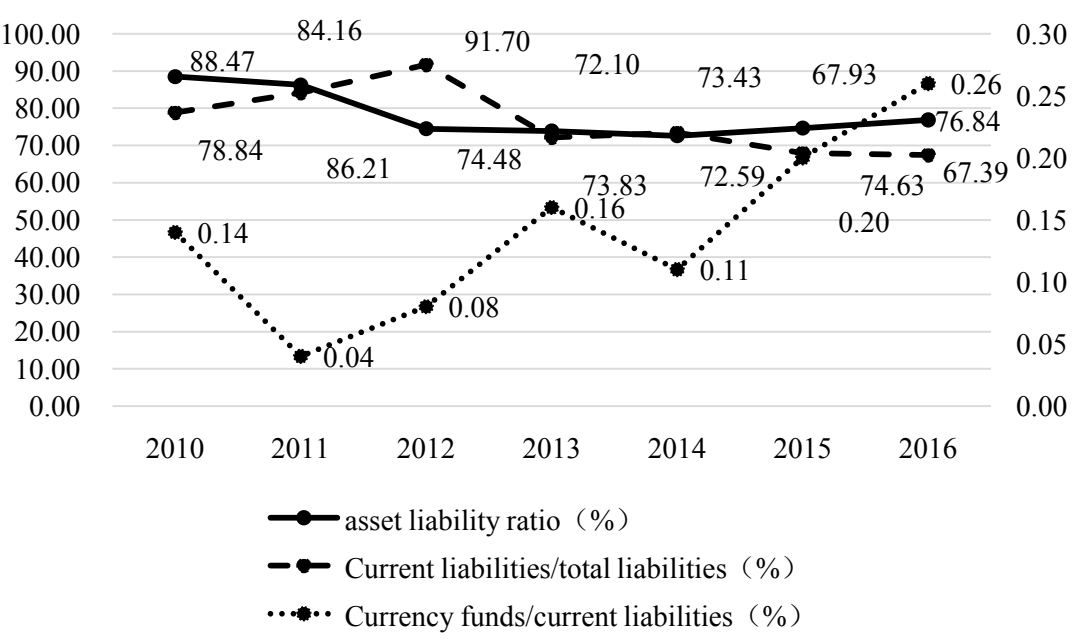

Figure 2. Greentown China's capital structure and solvency indicators. Data source: WIND. 


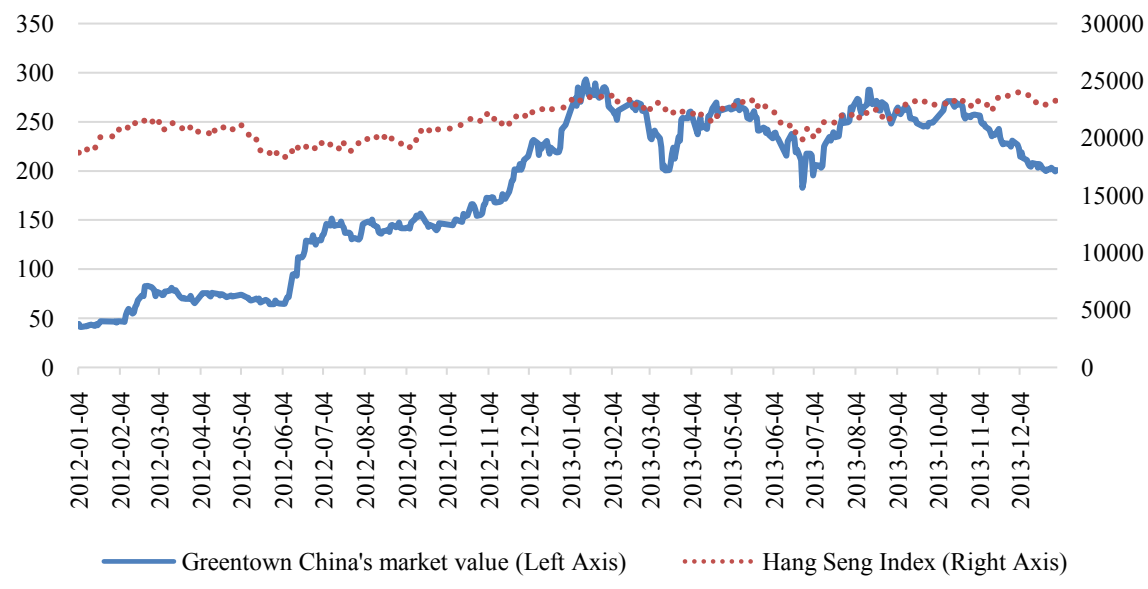

Figure 3. Changes of Greentown China's market value. Data source: WIND.

In 2012, after Wharf joined the Greentown China as a strategic investor, Greentown China accelerated the crisis with the attitude of changers. Focusing on reducing operational and financial risks and improving corporate efficiency, Greentown China achieved several key changes: First, it is the transformation from a self-operated model to a light asset operation model that includes diversified channels such as self-employment, commercial construction, government construction and affordable housing construction. The second is to establish the strategic transformation from pure high-end products to diversified product development more suitable for the market, and focus on old-age care real estate and tourism real estate. The third is to establish a transformation from the traditional self-owned team sales model to the brokerage system's national sales model. In addition, the company had successfully established a good brand image in the cities where it operates, with its excellent human resources reserve and high-efficiency group management structure and accumulated a large number of high-quality project development experience and outstanding operational capacity to provide a strong impetus for the rapid development of the group.

\section{2) Brand Value Improvement}

Greentown China has also become one of the best development companies in China after 2012. In the 201 China Urban Residents' Satisfaction Survey released by the China Index Academy, Greentown China not only ranked first in overall satisfaction, but also included the first of all six sub-items which are property services, product quality, planning and design, sales services, corporate image and customer loyalty.

\section{Research Conclusions}

This paper explores how strategic investors can use convertible bond investment and participate in corporate governance of investors and create value by using the case of Wharf Investment Greentown China Convertible Bonds from the relevant path of "value support-value driven-value realization". Strategic investors and bond-issuing companies have complementary resources and position- 
ing strategies to provide value support for cooperation between the two parties. The investment phase and corporate governance phase are key value-driven processes. In the investment phase, choosing the right financing method and designing the refined terms provide the basis for strategic investors to participate in corporate governance. In the stage of corporate governance, strategic investors can restrain excessive investment of bond issuers through sound financial policy output, and participate in investment decisions of bond issuers to create business synergies. From the perspective of the capital side, the asset-liability ratio of the bond-issuing enterprises will be effectively repaired, the financing cost will be reduced, and the market value will be improved. From the perspective of the industry, promoting strategic transformation, brand value enhancement, and operational improvement are all important embodiments of value creations. Through the above case analysis, we test and supplement the revised model of the value creation mechanism of strategic investors under the convertible bond investment, as shown in Figure 4.

Wharf through the convertible bond investment, as a strategic investor to participate in Greentown China's corporate management and corporate governance, creating value for it, has a certain typical significance and reference. This case provides a reference for strategic investor investment. In the past, strategic investor investment mainly focused on investment and shareholding research, while strategic investors can also participate in corporate governance of bond issuers through convertible bond investment. This paper expounds that the key elements of value-driven are the choice of financing methods, the design of convertible bond terms, and the further participation in corporate governance of bond issuers. Both parties can provide contractual constraints for corporate governance through detailed provision design, and then output financial and business policies, so as to create value for bond issuing enterprises and ultimately achieve win-win financial and strategic results of both parties.

It should be noted that this study involves internal investment decision-making, therefore the acquisition of research data mainly depends on the announcement of two listed companies and professional databases, which to some extent limits

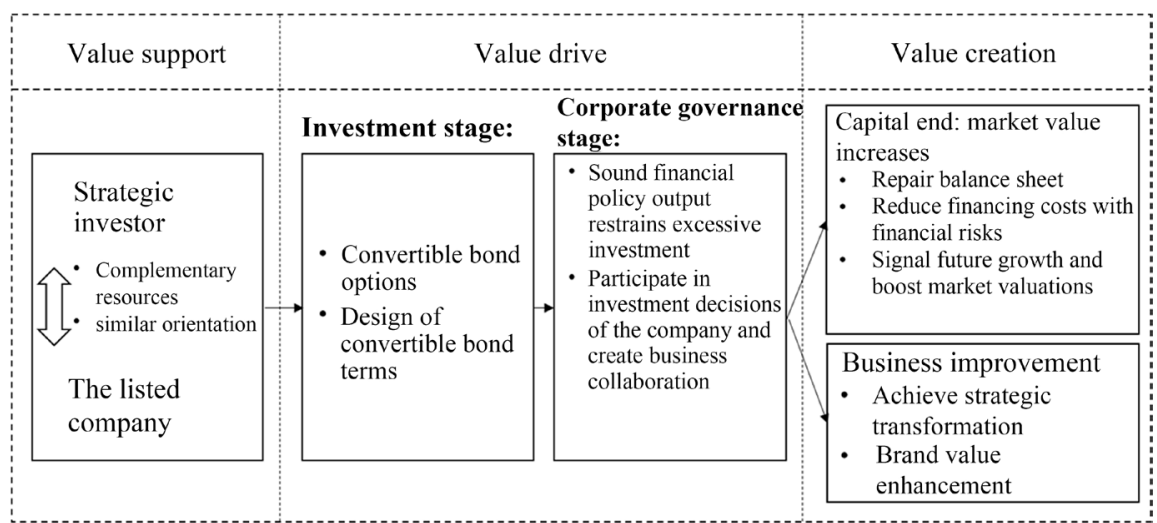

Figure 4. The value creation mechanism model of strategic investors under convertible bond investment. 
the deep discussion of the case. Moreover, this research is a single case study, and it needs further testing of large sample empirical research in the future.

\section{Conflicts of Interest}

The author declares no conflicts of interest regarding the publication of this paper.

\section{References}

[1] Wang, D.N., Jiao, S.L. and Wen, N.Q. (2009) Analysis of Redemption Strategy of Convertible Bonds Based on "Back Door Equity". Social Science Forum, No. 3, 78-81.

[2] Korkeamaki, T.P. and Moore, W.T. (2004) Convertible Bond Design and Capital Investment: The Role of Call Provisions. Journal of Finance, 59, 391-405. https://doi.org/10.1111/j.1540-6261.2004.00636.x

[3] Zhang, G.Q. and Lian, P. (2009) Convertible Debt Financing and Institutional Investors' Encroachment Behavior-Based on the Case Study of Hualing Pipeline Convertible Bonds. Management World, No. S1, 110-120, 133-134.

[4] Stein, J.C. (1992) Convertible Bondsas Backdoor Equity Financing. Journal of Financial Economics, 32, 3-21. https://doi.org/10.1016/0304-405X(92)90022-P

[5] Qu, W.Z. and Lin, Z.X. (2009) Actions for Convertible Bonds Issued by Chinese Listed Companies: "Backdoor Equity" vs "Agent Cost”. China Industrial Economy, No. 8, 141-151.

[6] Mayers, D. (1998) Why Firms Issue Convertible Bonds: The Matching of Financial and Real Investment Options. Journal of Financial Economics, 47, 83-102. https://doi.org/10.1016/S0304-405X(97)00038-X

[7] Green, R.C. (1984) Investment Incentives, Debt, and Warrants. Journal of Financial Economics, 13, 115-136. https://doi.org/10.1016/0304-405X(84)90034-5

[8] Zhu, J.G., Zhang, Q. and Tang, G.L. (2012) Convertible Bonds: Financing Tools or Institutional Arrangements-A Case Study Based on Bain Capital's Investment in Gome Convertible Bonds. China’s Industrial Economy, No. 5, 122-134.

[9] Sheng, Y.H. and Zu, J. (2014) An Empirical Study on the Impact of Different Types of Strategic Investors on the Performance of Listed Companies. Investment Research, 33, 120-129.

[10] Megginson, W.L. and Netter, J.M. (2001) From State to Market: A Survey of Empirical Studies on Privatization. Journal of Economic Literature, 39, 321-389. https://doi.org/10.1257/jel.39.2.321

[11] Berger, A.N., Hasan, I. and Zhou, M.M. (2009) Bank Ownership and Efficiency in China: What Will Happen in the World's Largest Nation? Journal of Banking \& Finance, 33, 113-130. https://doi.org/10.1016/j.jbankfin.2007.05.016

[12] Zhang, Z.Y. and Song, Z.J. (2010) Research on the Effect of Overseas Strategic Investors Holding Chinese Listed Banks. Nankai Management Review, 13, 106-114.

[13] Yin, X., Wang, W. and Lin, X. (2009) Empirical Analysis and Supervision of the Introduction of Strategic Investors by Listed Companies in Yunnan Province. Economic Problems Research, No. 12, 133-139.

[14] Zhang, S., Zhang, H. and Zhang, S. (2012) Research on the Introduction of Strategic Investors by Small and Medium-Sized High-Tech Enterprises in China. Economic Outlook of the Bohai Sea, No. 6, 21-23. 
[15] Li, J. and Jin, Z. (2007) Research on Partner Selection, Cooperation Relationship and Alliance Performance of Strategic Alliances. Science of Science and Technology Management, No. 11, 161-166.

[16] Lu, Z. and Guo, W. (2016) Research on Value-Driven Market Value Management Model-A Case Study of Market Value Management of Jiesai Technology. Financial Monthly, No. 31, 87-90. 